\title{
A középkori Magyarország településhálózatának térképes dokumentumai
}

\author{
Varga Csaba Gergely
}

DOI: https://doi.org/10.30921/GK.71.2019.2.4

Absztrakt: A középkor során kialakult, majd a török háborúk során elpusztult magyar településhálózat rekonstrukciója hatalmas feladat. A több mint tízezer elpusztult település kevesebb, mint felének ismerjük a pontos elhelyezkedését. Az ELTE Térképtudományi és Geoinformatikai Tanszékén 2018 szeptemberében elindult kutatás fö célja ezen elpusztult települések lokalizálása és egy geoinformatikai adatbázisba foglalása. E munkához föként a különbözô, minél régebbi, térképeken bemutatott határnévanyagot használjuk alapként. Egyúttal célunk olyan térképi ábrázolás kidolgozása mely lehetôvé teszi nemcsak a településhálózat, de az egyes települések lokalizálásában meglévó bizonytalanság bemutatását is.

Abstract: The reconstruction of the network of settlements established in the Middle Ages, then destroyed during the Turkish Wars is an enormous task. We only know the exact location of less than half of the ten thousand razed settlements. The main goals of the research started by the ELTE Department of Cartography and Geoinformatics in September 2018 are to localize these destroyed settlements and to record them in a geoinformatics database. As a base for this work, we use various, older toponyms presented on maps. At the same time, our goal is to develop a cartographic representation which enables the presentation of not only the network of settlements, but the uncertainty in the localization of individual settlements as well.

Kulcsszavak: középkori településhálózat, elpusztult települések, határnevek Keywords: medieval network of settlements, destroyed settlement, toponyms

Az ELTE Térképtudományi és Geoinformatikai tanszékén 2018 szeptemberében elindult egy kutatási projekt, melynek célja a középkori Magyarország településhálózatának rekonstrukciója. A kutatás adatait felhasználva a tanszék el kíván készíteni egy az egész középkori országot és annak minden települését ábrázoló térképmúvet.

A középkori településekrôl tekintélyes ismeretekkel rendelkezünk, ezek forrásai fôként egykorú feljegyzések, okiratok és adólajstromok. Ezen feljegyzések alapján születtek meg a különbözô, a középkorra visszadatált, a településanyagot is összefoglaló, földrajzi múvek. Ezek közül a legjelentôsebb Csánki Dezsố „Magyarország történelmi földrajza a Hunyadiak korában” és Györffy György „Az Árpád-kor történeti földrajza" címú múve. Ezeken az összefoglaló alkotásokon kívül számos, egy vagy több megyét feldolgozó mú is született, illetve az 1970es évektôl sok helyi, kisebb területet feltáró régészeti kutatás eredményeként bukkantak középkori települések nyomaira. Ezen munkák alapján képet kaphatunk a középkorban létezett, de a késóbbi korok során elpusztult településekrôl.
A magyar államalapítás alapvetóen meghatározta a Kárpát-medence településhálózatának fejlôdését. Az Árpádháziak vezette közigazgatás kiépítése nyomán nagyszámú új helység jött létre, a településszám növekedése a középkor végéig folyamatos volt. A településhálózat azonban jelentősen eltért a ma megszokottól. A helységek túlnyomó többsége apró- és törpefalu volt, amelyek lakossága nem érte el az 500 fót. Nyugat-európai szemmel nézve jelentôs méretű város nem volt az országban. A középkor végén a legnépesebb helység a királyi székhely volt. Budán ekkor 14 ezren laktak, míg Párizsnak a 15. század végén közel 150 ezer lakosa volt, Bécsben pedig közel 50 ezer ember élt. A magyarországi településhálózatban a kis méretú települések domináltak, ezek viszont sûrûn helyezkedtek el egymás mellett. Jelentôs volt a földrajzi differenciálódás, ez mindig valamilyen földrajzi tényezôre volt visszavezethetô. A Kisalföldön sû́uún követték egymást a mezôvárosok és a falvak, míg az Alföld inkább aprófalvas volt. A középkori településhálózat, az élelmiszertermelési feltételek nyomán (megfelelô nagyságú múvelhető föld), nem nyúlt a bükkerdők szintjénél magasabbra, így a népesség elsôdlegesen a dombvidékeken, az alacsony hegyvidékeken és a szélesebb folyóvölgyek mentén sưrūsödött. A síkságok nagy kiterjedésú vízborítottsága miatt nem az Alföld és a Kisalföld volt a legsû́rúbben lakott terület. (Kisfazekas 2016, Szabó-Végh)

A népességgyarapodás és vele együtt a településhálózat fejlódése, mely a középkor során szinte folyamatos volt, a 16-17. század háborúi hatására megtört. Az ország középsô és déli vidékein hatalmas területek váltak lakatlanná, egész vármegyék néptelenedtek el, települések tömege pusztult el. Falupusztulás minden háborús idôszakban bekövetkezetett, de a mohácsi csatát követô 150 év pusztításának mértéke minden korábbi háborús idôszakét felülmúlta. A 18. század során a középkori településállomány sok helyen nem éledt újjá; fóleg a szervezett betelepítések által érintett területeken, új települések jöttek létre, új helyen. Ennek következtében (a török háborúk után) sok tekintetben egy új településhálózat alakult ki, mely a középkoritól egyes területeken (pl. Temesköz) teljesen eltérố képet mutat.

Annak ellenére, hogy hatalmas menynyiségú elpusztult településról tudunk, 
ezek helyzetének pontos meghatározása akkor is nehéz feladat, amikor a települések neve és valamilyen helyadat rendelkezésünkre áll. Ennek oka, hogy az adatok nem megegyezô minôségúek, így pontos térképi ábrázolásukra nem mindig van lehetôségünk. Kartográfiai szemszögből egy elpusztult középkori településrôl a rendelkezésre álló adatok alapján három nagy fogalmi csoportot tudunk felállítani. Ezek a lokalizáció pontossága alapján születtek: 1) pontosan lokalizálható, 2) megközelítôleg lokalizálható, 3) nem lokalizálható.

A pontosan lokalizálható (1) csoportba soroljuk az összes olyan települést, amely ma is élô vagy valamilyen megmaradt építmény, régészeti lelet alapján egy adott (ismert) földrajzi helyhez köthetô. Felszíni lelet hiányában, a források alapján egyértelmúen azonosítható, a terepen néhány négyzetkilométernyire behatárolható területhez köthetô.

A megközelítôleg lokalizálható (2) csoportot két típus építi fel. Egyrészt azok a települések alkotják, amelyek egykori elhelyezkedése a rendelkezésre álló források alapján nem szúkíthetô le néhány 10 négyzetkilométernél kisebb területre. Ugyanakkor azok a helységek is ide tartoznak, amelyekrôl van forrásunk, de azonosításában nem vagyunk egészen biztosak. Többnyire földrajzi nevek adnak ilyenkor segítséget. Sok egykori helység neve ma is élő határnévanyagban ôrzôdött meg. Ezek azonosítását nehezítheti az újkori etnikai változásokkal együtt járó nyelvi átalakulás. Amikor a település nevéhez hasonló hangzású idegen névalak ôrzôdött meg, de egy másik nyelven, akkor a megfeleltetés kérdéses.

A nem lokalizálható (3) csoportba tartozik minden olyan település, amely helyzetéről nem rendelkezünk megfelelố topográfiai adatokkal, így a helység nem helyezhetô el egy közepes méretarányú térképen. E csoport létjogosultságát elsôsorban az adja, hogy a település egykori létérôl tudunk, de sokszor csak annyit, hogy melyik vármegyében feküdt.

A települések helyzetének meghatározására a térképi ábrázolás a legmegfelelőbb. Ugyanakkor a középkor folyamán csupán kis méretarányú térképek készültek Magyarországról. A legnagyobb méretarányú, komoly névanyaggal rendelkezố térképmú az 1528-ban kiadott Lázár deák féle térkép, mely kb. 1: 1200000 méretarányban ábrázolja a középkori Magyar Királyságot, és annak közel 1400 települését. Az 1400 település közül a legtöbb napjainkban is létezik, azonban a térképen szerepel néhány olyan is, amely 1528 óta megsemmisült. Egyúttal szerepelnek a térképen olyan helynevek, melyek ma nem azonosíthatóak egyértelmúen. Csak egy példa a középkor óta megsemmisült település ábrázolására: a By néven szereplô település megegyezik az egykori Bô nevú faluval. (1.ábra) Ennek a Somogy megyei Bodrog határában, Kaposvártól északra, a mai Búpuszta ôrzi a nevét. (Stegena 1982, Plihál 2013)

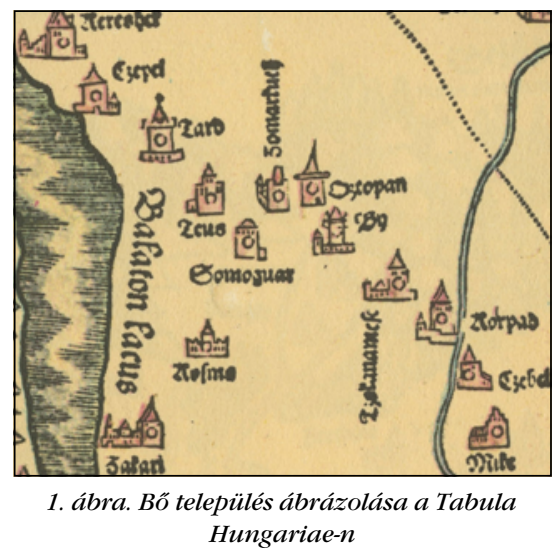

Az egykorú térképes források hiánya nem jelenti azt, hogy semmilyen formában nem maradtak fent térképen a középkori települések nevei. Rengeteg, hajdan volt helység neve ôrzôdött meg a határnévanyagban. Ennek oka, az hogy a település egykori helyét annak pusztulása után is a település nevével jelölte a környéken megmaradt vagy betelepült népesség, ezzel megốrizve a nevet az utókornak. A név az idők során gyakran kiegészült földrajzi köznévvel, leggyakrabban a „puszta” szóval. Mindezek nyomán a határnévanyag, az egykori települések lokalizálásában a legfontosabb forrásnak tekinthetô.

A határnevek lokalizációra való felhasználásakor sokféle probléma merül fel. Jellemzó, hogy a középkorban a latin nyelv betûkészletével feljegyzett településnév és a határnév sokszor jelentôsen eltér egymástól, nehezítve ezzel az azonosítást. Ennél is komolyabban hátráltatja a határnévanyag felhasználását az azóta végbement etnikai átalakulás és annak következményei. Ilyen esetben szinte mindig történt névátvétel, de ilyenkor az adott földrajzi nevet az odaérkezô népesség kisebb-nagyobb mértékben a saját nyelvére formálja. Ez lehet hangzásbeli, így írott formában jelentkezô változás, de lehet a név egy részének vagy egészének fordítása is. Teljes névfordításkor, amennyiben az elpusztult település neve szónév volt, ismét kérdésessé válhat az azonosítás. Az azonosíthatóság leginkább akkor maradt meg, amikor a határnévként tovább éló egykori településnév az átvevố népesség nyelvében csak helyesírási különbséggel marad fenn. (Faragó 2014)

A fentebb vázolt okokból kifolyólag a középkori települések lokalizálására olyan térképmúvek lehetnek leginkább alkalmasak, amelyek méretarányuknál fogva jelentôs határnévanyaggal rendelkeznek. A határnevek változékonysága (a legsérülékenyebb, legkönynyebben megváltozó, eltúnô földrajzi nevek) miatt a lehetố legkorábbi, a középkorhoz időben legközelebb álló térképek a legalkalmasabb a vizsgálatok elvégzésére.

Az elsố katonai felmérés szelvényeinek határnévanyaga meglehetôsen hézagos; a fôként német felmérôk a magyar nyelvú határneveket gyakran elírták, és a neveket sokszor nem megfelelő helyen ábrázolták. Ebból kifolyólag a második katonai felmérés sokkal jobb alapot nyújt a határnevek között megbúvó településnevek felkutatására. Ezeken a szelvényeken már több határnév található, mint az elsố felmérésén, helyesírásuk is megbízhatóbb, sokkal biztosabb a térbeli elhelyezkedésük is. A harmadik katonai felmérés névanyaga határnevek szempontjából a legbôvebb, jelentôsen több név található rajta, mint a megelốzô felmérések szelvényein, ugyanakkor e szelvények készítési ideje már jócskán eltávolodik a középkortól. A harmadik katonai felmérés szelvényeinek olvashatósága - fôleg hegyvidékes területeken - a csíkozásos domborzatábrázolás sötét tónusa miatt nehézkes lehet. (Jankó 2007) 


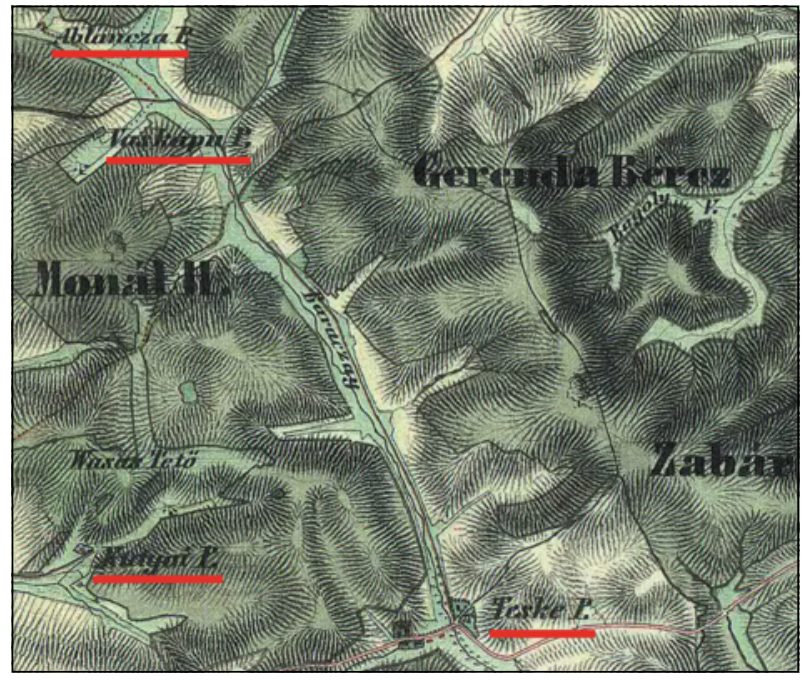

2. ábra. A második katonai felmérés Section 42 Colone XXXVII szelvényének részlete a különbözố kataszteri térképeken, így ezek is tartalmaznak egykori települések helyét rejtő neveket.

A középkori településhálózat ábrázolása eddig leginkább kis méretarányú térképeken történt, nagyobb méretarányokban szinte csak egy-egy megyét feldolgozó munkák születtek. Az egész országot bemutató, talán legrészletesebb térképek Györffy György „Az Árpád-kor

A 2. ábrán látható terület remekül példázza a második katonai felvételen megőrződött településneveket. A Kutyai puszta megfelel az egykori Kutya nevú településnek, Györffy György leírása alapján: „Ma psz. Rakottyás határában, Rimaszombattól K-re.” Ugyanígy biztosak lehetünk abban, hogy az egykori Téske települést a mai Teske puszta területén kell keresnünk (Györrfy György: Ma puszta Füge m. d. [helyesen: ny.]), Ablánca puszta az egykori Ablonc település helyén áll (Györffy György: „Ma psz. Gömör és Rimaszombat között, Gömörmihályfalva határában DNy-ra és Uzapanyit határában K-re.”), Vaskapu puszta pedig megfelel az egykori Vaskapu falunak (Csánki Dezső: „Ma puszta Rakottyás és Kálosa közt.").

Nagyon hasznos forrást nyújtanak a határnevek közti településnevek azonosítására a 19. században készült kataszteri felmérés lapjai. A 20. század történéseinek következtében az egész középkori ország területére nem áll rendelkezésre olyan újabb összefoglaló anyag, amely lehetôvé tenné a határnevek tanulmányozását. Az egykori Osztrák-Magyar Monarchia utódállamainak nagy méretarányú térképezése különbözô szinten és méretarányban folyt, ráadásul sokhelyütt ideológiai okokból a magyar földrajzi névanyagot államnyelvi alakokkal cserélték fel. A mai ország területére nézve jelentôs mennyiségú határnév található a polgári topográfiai térképek 1:10 000 méretarányú szelvényein és

Összegezve: a középkori Magyar Királyság településhálózatáról, bár sok a hiányosság, nagyszámú írott forrással rendelkezünk, amelyeket jól kiegészítenek a régészeti kutatásokból származó adatok. Utóbbiak egyre nagyobb számban jelenek meg, de együttes, összegző feldolgozásuk még várat magára. Sok egykori helység esetében gyakran támaszkodhatunk a határnevekben konzerválódott nevekre. Így rendelkezésre állnak olyan források, amelyekre támaszkodva létrehozható egy, a mai kor követelményeit kielégítő térbeli adatbázis a középkori Magyar Királyság településszerkezetérôl.

\section{Irodalomjegyzék}

Faragó Imre 2014. Földrajzi Nevek. Eötvös Loránd Tudományegyetem Informatikai Kar. Budapest, pp. 13., 268-278.

Jankó Annamária 2007. Magyarország katonai felmérései 1763-1950. Argumentum Kiadó, Budapest pp. 25-27., 66., 97.

Kisfazekas Kornélia 2016. A Magyar településhálózat fejlődése és értékelése 3 . In Szabó Julianna (szerk.): URB.0 Urbanisztika kezdőknek, BME Urbanisztika Tanszék, Budapest.

http://urb.bme.hu/segedlet/varos1/URB.0URBANISZTIKA-KEZD\%C5\%90KNEK\%20 -\%20KISSFAZEKAS.pdf

Utolsó elérés: 2019. február 28.

Stegena Lajos 1991. Magyarország térképei a mohácsi vész elôtt. Alföldi Nyomda, Budapest

Stegena Lajos 1982. Lazarus secretarius. The first Hungarian mapmaker and his work. Akadémiai Kiadó, Budapest. pp. 32-33.

Plihál Katalin 2013. Tabula Hungariae.. Ingolstadt, 1528 térkép és utóélete, OSZKKossuth Kiadó, Budapest

Szabó Imre. Magyarország településszerkezetének rövid története. http://www.sze.hu/mtdi/gyoreuropa/ R\%E9sztematik\%E1k/Szab\%F3\%20Imre\%20 Mo\%20telep\%FCl\%E9sszerk\%20rv.\%20 t\%F6rt.doc

Utolsó elérés: 2019. március 3.

Végh András. Buda város törté nete a kezdetektôl 1541-ig. http://budavar.btk.mta.hu/hu/helytortenet/ buda-varos-tortenete-a-kezdetektol-1541-ig. $\underline{\text { html }}$

Utolsó elérés: 2019. február 28

Egyéb források:

Dr. Csánki Dezsô 1890-1941. Magyarország történelmi földrajza a Hunyadiak korában I-V. Magyar Tudományos Akadémia, Budapest.

Györffy György 1963-1998 Az Árpád-kor történeti földrajza I-IV. Akadémiai Kiadó, Budapest.

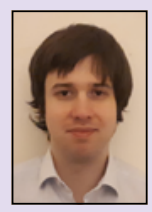

Varga Csaba

Gergely

II. éves MSc hallgató
ELTE Térképtudományi és Geoinformatikai Tanszék csabo93@map.elte.hu 